\title{
SOME VIEWS OF ELITE ATHLETES ON COOPERATION WITH THE MEDIA AND THE MEDIA'S INFLUENCE ON SPORTS AND PRIVATE LIVES
}

\author{
Marko Zadražnik*, Mojca Doupona Topič
}

Faculty of Sport, University of Ljubljana, Ljubljana, Slovenia

Submitted in August, 2010

BACKGROUND: Today, sport represents an element of the quality of life as it is often an indicator of a country's civilisational, societal and economic development. The public is mostly interested in elite sport which has effects for both society as well the lives of individuals as the public is not only interested in sports achievements but also in athlete's private lives. The border between the public and private is difficult to establish. The interlinked work of elite athletes and the media often results in misunderstandings as the media intrudes on the private lives of athletes, which in turn impacts both the private and professional lives of athletes.

OBJECTIVE: The study's main purpose was to identify the attitude of elite athletes to the media and the influence of the media on the private and professional lives of athletes. The study also evaluated the qualities of an ideal journalist in the eyes of athletes.

METHODS: Differences between more and less experienced elite athletes were studied on a sample of 67 Slovenian athletes from team sports. The data were collected through a questionnaire. The findings were further interpreted in line with the opinions of ten leading athletes from individual sports, which were collected through a semi-structured interview.

RESULTS: Differences between groups of more and less experienced athletes were detected in answers to the question, "When do athletes decide to cooperate with the media?" and "Have you already been offended by the media?". Elite athletes like to cooperate with the media and usually give information away freely. Similarly, journalists largely understand that athletes desire peace and quiet prior to a competition. Athletes perceive precision and verification of information as the most important qualities of journalists, while they consider some personal qualities and materialistic characteristics as less important.

CONCLUSIONS: The study's results show that in the future athletes would like journalists to write articles that offend them less, regardless of whether the published information is about their sports achievements or private lives.

Keywords: Media, reporting, privacy, public, sport.

\section{INTRODUCTION}

Sports have formed a part of nearly every society's culture throughout human history. For most of this time, sports were dominated by local customs and attracted a following that was relatively localised. The advent of mass media changed this (Delaney \& Madigan, 2009). As a result of globalisation, sport has become a social phenomenon which does not serve its own purpose but is willing to change and adapt to the public (Tomlinson, 2005). Its importance affects both society and the individual. It represents a quality of social life and it is often an indicator of a society's civilisational, social

\footnotetext{
* Address for correspondence: Marko Zadražnik, Faculty of Sport, University of Ljubljana, Gortanova 22, 1000 Ljubljana, Slovenia. E-mail: marko.zadraznik@fsp.uni-lj.si
}

and economic levels. Sport is a mixture of economics, politics, science and other areas of life; without enormous capital investments by business it could not shine and create such an atmosphere. Similarly, nowadays it is unimaginable not to be surrounded by various types of media. Every single day brings about more news on $\mathrm{TV}$, radio, newspapers and the Internet. If two decades ago the main sources of socialisation were one's family, peers and school, today the media also represents a socialisation factor that forms social values with its stereotypes and defines people's views with its clichés. The media has the power to form a social space with behavioural patterns on offer; it supplies various types of information and constantly intrudes on people's everyday lives. Media sports, like other parts of culture, are social constructions (Rowe, 2004, 2007; Wenner, 1998; Whannel, 2002). They are created, organised and controlled by human beings whose ideas are grounded in their social worlds, experiences and ideologies. The 
media does not reflect reality as much as provides representations of selected versions of reality. As Coakley (2011) suggested, power relations in society influence these representations.

Similar to the media, elite sport is also part of everyday life and elite athletes are idols for many people. Spectacles, records, enjoyment, victory, fame etc. are followed by the media; nevertheless, they do not always satisfy the principle of objectivity and ethics. Athletes are big stars, often bigger than actors, musicians or politicians. It is this very fact that explains why the public is interested not only in the athletic achievements of athletes, but also their private lives. The borderline between the private and the professional is difficult to set even for serious media establishments which do not wish to comment on the private lives of athletes (and their problems) as they have no relationship with their sports lives (training and/or competition). Yet, in contrast, there are scores of so-called sensationalist media establishments publishing information particularly about athletes's private lives, often forcing the serious media to follow suit.

This entangled work of elite athletes and the media often results in various strains between them (Hardt, 1999; Schudson, 2001). The media is increasingly intruding on the private lives of athletes, sometimes creating a nuisance for them. Complaints are often made about journalists following athletes in their every step, or journalists forcing themselves on athletes and disregarding their desire for privacy. It also happens that athletes blame the pressure of the media for their failure. On the other hand, the media are a link between the sport and the public which wishes to know as much as possible about athletes. People are no longer satisfied with mere results and statistics. In this way, the public puts pressure on journalists who, in response to their wishes and the demands of editors, write articles in a way to satisfy people. Consequently, pressure is placed on athletes who often feel threatened as they are constantly monitored by cameras and journalists. It is particularly hard when the media offend athletes (or the people close to them), especially when this influences their performance or career (Zelizer, 2004).

Sports journalism or reporting about sport is a special area of journalism. Boyle (2006) evaluated sports journalism as a paradox of its own - it is traditionally regarded as a lesser sort of journalism, although in reality it holds large commercial importance, particularly in the popular and mass media. Rowe (2007) stated that the majority of sports articles are routinely neutral; however, he also warned that sports pages in newspapers are not homogeneous. Namely, they consist of a series of stories from reporting about major sports events to short notices. Some forms of sports journalist genres contain art and literature, whereas others come close to political campaigns (Rowe, 2004; Boyle, 2006). The results of the International Sports Press Survey 2005 (Rowe, 2007) indicate that sports journalism is chiefly focused on the prediction of sports results and describing a sports event; at the same time, sports journalism avoids the discussion of problematic social topics and largely relies on the opinions of influential people from the field of sport (Fink, 1988, 2001).

Objectivity is most often mentioned by the public as the central task of journalists' work (Deuze, 2005; Schudson, 2001); nevertheless, media experts and theoreticians agree that the objectivity of journalists is impossible to achieve for objective and subjective reasons, such as limited knowledge and involvement in the flow of events as a member of society. Slovenian journalists in their (self) regulatory articles state "the right of the public to the best available information" as the leading guideline for journalists (Code of Ethics of Slovenian Journalists, 2002) who in their work have "a responsibility to present the entire picture of events". The word objectivity is not explicitly written in the Code. In particular, McKnight (2001) describes the objectivity of journalists as a guarantee of a journalist performing "consistent attempt" to explain an event unbiased way with the use of reliable sources. Kovach and Rosenstiel (2007) described objectivity as part of the ideology of journalism with characteristics of being unbiased, undefined, objective, fair and credible. In Slovenia, truthfulness is mentioned as a central moral guideline of journalists (Kodeks, 2002).

Sports journalism is an important part of the print media, but in the literature it is noted that is not one of the most prestigious journalistic disciplines. It is often attributed the image of the "children's department of print media" (Rowe 2004), subject to a comfortable life, sloppy journalism and "soft" news, even though, on the other hand, sports journalism enjoys a high status in daily newspapers. Sports reporters have a wide range of readers, but they are little appreciated. It is a false ideology (the assumption that toys and play are not serious and meaningful) derived from the traditional, classroom-based and patriarchal view of the press and popular culture in general, especially in sports (Tomlinson, 2005). The American sports reporter $\mathrm{H}$. Cosell first used the term "sport is a children's department of human life" (O’Brien, 2007) which is consistent with the memory of his sports journalism reporting becoming a children's section of the print media.

At first sight, the influence of sports journalists on the public is noticed in at least two dimensions - first, with the use of vocabulary and second, with creation of the reference frame or by channelling the perception of spectators (by creating "ours" and "not-ours" athletes). According to Entman (1993), media framing is the practice of choosing certain aspects of perceptual 
reality and emphasizing them in reporting through the promotion of a certain definition of a problem, causal explanation, moral evaluation and/or recommending the behavior relative to the described event (Merrill, 1997). A summary of audience research done by media studies experts Wenner and Gantz (1998) indicates that US adults integrate media sports into their lives in a variety of ways. We know that media images and narratives influence people, but we do not know much about who is influenced or in what ways people are influenced. Media coverage is part of our experience as Coakley (2011) stated, and experiences influence who we are and what we think, feel and do.

The purpose of the article is to present the opinions of Slovenian elite athletes about the work of the media, cooperation with the media and the effect of the media on their private and sports lives. The way the media reports about a particular athlete depends on the kind of information they possess about that athlete. The study examined when and how often elite athletes cooperate with the media and about which topics they are prepared to talk. Usually elite athletes desire peace and quiet prior to their performances while, conversely, journalists are particularly interested in pre-competition information. Therefore, the study also examined how this pre-competitive "imposing" affects athletes and their performances. On the basis of the experience of athletes the study also examined what type of media intrudes on the private lives of athletes and which content offends athletes and the people close to them the most. Finally, the article presents findings about the qualities which define a good journalist.

The quality of athletes's cooperation with the media depends on several factors - being taught about ways of cooperating with the media, being familiar with the code of ethics of journalists, the ability to express oneself and, of course, on the frequency of cooperation (e.g. experience in this area). Therefore, differences between more and less experienced elite athletes were examined (Doupona Topič, 2005).

\section{METHODS}

The study included 67 Slovenian elite athletes (50 males - $74.6 \%$ and 17 females - 25.4\%) involved in team sports (ice hockey $-20.9 \%$, volleyball $-29.9 \%$, handball $-29.9 \%$, football - $19.3 \%$ ). Their previous participation in sport ranged between 4 and 25 years, with an average of 15.1 years and a mode of 10 years (16.4\%). In relation to previous sport experience, the sample was divided into two subgroups (i.e., less experienced < 14 years; and experienced > 14 years). In Slovenia, selection in team ball games starts around the age of ten, meaning that athletes train in younger age categories for approximately eight years before enter- ing senior teams. The career of elite athletes lasts well into their thirties; therefore, the theoretical borderline between less and more experienced athletes was set at 14 years of participation in sport.

The survey also included ten Slovenian elite athletes (five males and five females) from individual sports. Their opinions were used to further clarify the relationship between the media and athletes.

The sample of variables is represented with four sets of questions. The first set was used to examine some general characteristics (age, gender, chosen sport, participation length, education and profession). The second set was used to examine the attitude of elite athletes towards the media (level of willingness to cooperate, topics they are willing to discuss). The third set of questions examined the media's influence on the private and professional lives of elite athletes (being burdened by the media's reporting, the intrusion of the media before a competition, knowing the code of ethics of journalists etc.). The fourth set was used to examine the qualities athletes value in journalists (model of a quality journalist). Athletes were presented with a list of qualities (kind-heartedness, respectfulness, quality writing, precision, verifying information, impartiality, rudeness, friendliness, self-control, own decision-making, self-evaluation, following the rules and interests of the employer, care for financial success). The interviewed subjects evaluated their importance on a five-level scale (not important at all $=1$, not important $=2$, partly important $=3$, important $=4$, very important $=5$ ).

Descriptive statistics were computed for all variables. For the Likert scale variables medians and quartiles were computed from the grouped data (assuming values of scale are group midpoints). The association (i.e. differences in row structures) between nominal variables were evaluated with Cramer's $V$ coefficient; note that this coefficient is equivalent to $\chi^{2}$ test for two-way contingency tables, so it's statistical significance ( $p$-value) is the same for both statistics. Somer's $D$ coefficient was used to measure association in all cases where both variables were ordinal. Differences in central tendency between the groups of more and less experienced athletes were tested with non-parametric Mann-Whitney $U$ test.

Semi-structured interviews according to Andrews, Mason, and Silk (2005) were used to collect the opinions of the ten best Slovenian elite athletes. Their statements were later used to supplement the opinions of the athletes involved in team sports.

\section{RESULTS}

The interviewed subjects ranged in age between 17 and 33 years, with an average of 25.2 years. Re- 
garding age, a difference (Cramer's $V=0.281$; $p=.022)$ was found between the less experienced $(<19$ years $=24 ;>19$ years $=11)$ and xperienced athletes $(<24$ years $=13 ;>24$ years $=24)$. Conversely, no difference $(V=0.254 ; p=.506)$ in education emerged between the groups. In particular, $59.7 \%$ of the athletes had graduated from high school, $7.5 \%$ from primary school, $16.4 \%$ from vocational high school, $14.9 \%$ hold a university degree, whereas only one athlete declared having no formal education.

The sample included professional athletes (74.6\%), university (14.9\%) and high school (6\%) students, entrepreneurs (3\%) and a government employee (1.5\%). Although the experienced group included 9\% more professional sports competitors than the group of less experienced athletes, no difference emerged with regard to experience $(V=0.346 ; p=.092)$.

Both groups share similar opinions about cooperation with the media $(V=0.156 ; p=.652)$. However, $70.1 \%$ of the athletes declared they are available for an interview regardless of the type of media involved, whereas $19.4 \%$ decide to cooperate only when the media is considered "serious". Only one athlete (1.9\%) usually turns the media down, while six athletes (9\%) want to know the topic before deciding whether to be interviewed.

A difference $(V=0.351 ; p=.016)$ between the groups emerged with regard to answering a topic of interest to a journalist. Among the less experienced athletes, only 14 cooperate when the topic relates to sport, whereas only two of the experienced athletes share this opinion. However, among experienced athletes 12 rarely agree to be interviewed if the topic of the questions is not sport-related.

Before a match, the majority of the athletes (76.2\%) follow (read, watch, listen to) available media, 17.9\% do not follow anything about sport, $6 \%$ only follow articles about the opponents, whereas no athlete follows articles relating to themselves. Regarding reading, watching or listening to news about themselves or their opponents before competitions, no difference between the groups $(V=0.025 ; p=.979)$ was found.

In relation to media pressure, no difference $(V=0.156 ; p=.442)$ between the groups emerged. Most $(62.7 \%)$ of the athletes did not consider themselves to be under media pressure, $35.8 \%$ declared that sometimes they had been under heavy media pressure, and only one player (1.9\%) stated they had often been under heavy media pressure before a match. Further, the athletes have relatively good experience with the media prior to a match as $56.7 \%$ of them declared that journalists understand when they do not wish to be interviewed and respectfully leave them alone. Eight athletes (11.9\%) considered that journalists persist for a while before giving up. Conversely, eight athletes claimed that sometimes journalists do not give up (11.8\%), whereas $6 \%$ stated that they have to be discourteous to get rid of a journalist. Further, $13.6 \%$ of the athletes listed other reactions of journalists when being turned down for cooperation before a match.

Only $37.3 \%$ of the athletes have never been offended by the media. In particular, daily newspapers, the internet, TV programmes related to sport, and "yellow press" were reported as often being offensive, whereas radio and TV programmes not related to sport were seen as more respectful. The less experienced athletes were offended less often or had not been offended by the media yet $(V=0.369 ; p=.028)$ with respect to those athletes who are often offended by partially or completely untrue information. In particular, the question "Has anyone close to you been offended due to published information?" revealed no difference $(V=0.256 ; \mathrm{p}=.357)$ regarding sport experience. The majority $(79.1 \%)$ of the athletes answered in the negative, whereas the others reported that their friends and/ or partners had been offended. Although no difference between the groups was found regarding the media's influence on the private lives of the athletes ( $V=0,182$; $p=.328)$, untrue information had influenced their private lives $(83.6 \%)$, with four athletes $(6 \%)$ reporting having experienced it a few times and seven athletes (10.4\%) stating that they had been offended only once.

No difference $(V=0.236 ; p=.154)$ emerged between the groups regarding the media's influence on the sports lives of the athletes. However, five athletes declared that the media had affected their sports life several times and two answered that it had happened once. Independently of sports experience, the athletes considered it most important for journalists to provide precise, accurate and verified information. These values are followed by personal characteristics, whereas the materialistic characteristic was last.

Regarding knowledge of the Code of Ethics of Slovenian journalists, no difference $(V=0.237 ; p=.288)$ was shown between the groups. Twenty-four athletes were unaware of its existence, 21 were not completely sure of its contents, 20 were aware of its contents even though they had not read it, and only 2 had actually read it.

\section{DISCUSSION}

The present findings reflect the opinions of elite Slovenian team athletes regarding sport media. With respect to gender, male athletes were represented more $(74.6 \%)$ than their female counterparts $(25.4 \%)$, probably due to the absence of elite Slovenian women's ice hockey or football teams. The age difference between the groups may be logically ascribed to the distribution of the sample according to the sports experience of the players. 
Table 1

Parameters of distribution of characteristics of good journalists, Mann-Whitney U test and Somer's D test for the differences between less and more experienced athletes

\begin{tabular}{|c|c|c|c|c|c|c|}
\hline & \multicolumn{2}{|c|}{$\begin{array}{l}\text { Less experienced } \\
\qquad(n=32)\end{array}$} & \multicolumn{2}{|c|}{$\begin{array}{l}\text { Experienced } \\
\quad(n=35)\end{array}$} & \multirow[b]{2}{*}{ Mann-Whitney $U$} & \multirow[b]{2}{*}{ Somer's $D$} \\
\hline & $M d n$ & IQR & $M d n$ & IQR & & \\
\hline Kind-heartedness & 4.11 & 1.23 & 4.39 & 1.16 & $417^{*}$ & $.23 *$ \\
\hline Respectfulness & 4.50 & 1.07 & 4.59 & 0.93 & 515 & .08 \\
\hline Quality writing & 4.36 & 1.28 & 4.49 & 1.09 & 497 & .11 \\
\hline $\begin{array}{l}\text { Accuracy, precision, } \\
\text { verifying of information }\end{array}$ & 4.61 & 0.90 & 4.63 & 0.87 & 551.5 & .02 \\
\hline Impartiality & 4.15 & 1.34 & 4.28 & 1.22 & 508.5 & .09 \\
\hline Arrogance & 2.76 & 1.86 & 2.47 & 2.07 & 516 & -.08 \\
\hline Friendliness & 3.90 & 1.50 & 3.64 & 1.36 & 482 & -.14 \\
\hline Self-control & 3.80 & 1.36 & 3.50 & 1.29 & 443 & -.21 \\
\hline Own decision-making & 3.66 & 1.22 & 3.48 & 1.34 & 483 & -.14 \\
\hline Self-evaluation & 3.75 & 1.45 & 3.44 & 1.15 & $437.5^{*}$ & $-.22 *$ \\
\hline $\begin{array}{l}\text { Following the rules and } \\
\text { interests of the employer }\end{array}$ & 3.27 & 1.59 & 3.32 & 1.54 & 543 & .03 \\
\hline Care for financial success & 2.95 & 1.72 & 2.91 & 1.59 & 552.5 & -.01 \\
\hline
\end{tabular}

Note. $\quad M d n=$ median, $\mathrm{IQR}=$ interquartile range

$*$ = two-way exact $p$-value $<.10$

Elite sport requires a lot of time for training and competitions, which lengthens the time needed to obtain an educational qualification. It is interesting to note that, independently of athletic level, athletes mirror the education level of the general population (Kustec Lipicer \& Doupona Topič, 2012). In general, our sample mainly included professional athletes, meaning that sport is their way of earning a salary, allowing them to concentrate on their training and competitions.

The majority of the athletes agree to cooperate with the media regardless of the particular type involved. It could be speculated that athletes realise the importance of the media's role in today's society and the mutual benefit of cooperating with media people. In fact, the audience is interested in the lives of the "stars", including the most successful athletes. Further, the majority of professional athletes largely depend on sponsors, which are naturally interested in media appearance advertising. In particular, athletes try to manage their relationship with the media in different ways. For example, one sports person stated: "You say what you think you can say, sometimes a bit more. I got used to it - when things get out of hand, I require an authorisation of texts before the interview is published. It happens that many things are wrongly interpreted. Journalists do not deny the authorisation of a text when required."

The level of athleticism does not influence the strong interest in media reports on athletes, with young athletes using the internet more than their older counterparts. It is interesting to note that before competitions athletes tend not to read articles about themselves. In fact, the majority of journalists are perceived as being respectful of the athletes' need for peace before a match, although others are perceived as being very aggressive when trying to obtain exclusive news. In particular, one sportsperson claimed: "Journalists do not understand or do not want to understand that I do not want to be disturbed before a competition. You cannot completely impede them but you can set some limits. I first set a limit during the Sydney Olympic Games. Although I had agreed to meet regularly, before a competition I did not want to be disturbed. Further, immediately after the competition I performed my routine tasks before being available to the media. Since then, I have tended to stick to the same rules. Journalists seem to have accepted it well, perhaps due to my good athletic outcome. I wonder if it would have been different had the results been bad." Moreover, a Slovenian swimmer described his unpleasant experience with the media: "At the world championships in Indianapolis, where the time difference was eight hours in comparison to Slovenia, Ifinished third on the second day of races. At six in the morning, a journalist called me by phone asking me to comment on my performance because he had to send his article urgently to the newspaper. I was sleep deprived and the next day I finished fourth. On that day there was no call before 
or after my performance. When I won a race, the media started calling again. Usually, I do not receive so many phone calls, however now I switch my phone off and I ask the hotel concierge not to put calls through, although sometimes journalists even manage to do that."

Partially or completely untrue information often offends the athletes. As expected, the less experienced athletes had been offended significantly less than their experienced counterparts, or indeed the media had not offended them yet. In fact, media interest increases over time, particularly when athletes are successful. Naturally, a longer sport career provides more opportunities for successful results. As the media strives for large audiences, journalists often scrutinise the past and present lives of athletes, looking for any missteps to arouse public interest. In general, the athletes perceived that they had mostly been offended by daily newspapers, followed by the Internet, TV sport programmes and yellow press. Conversely, radio and TV programmes not related to sport are seen as being more respectful. Those who had not been offended by the media claimed they would complain to the media if offended. In reality, it is rare for athletes to call an editorial board to complain or to ask for an apology when actually offended. One skier described his experience as follows: "Once in my career I was offended by an article printed in the Slovenian news in which it had been reported that I had demanded an enormous amount of money to participate in a charity event, which was a complete lie. I have never received any payment for charity events and I think I am the most active sportsman when it comes to participating in charity events. The news that offended me was published on the front page with a large heading..."

In addition, a female skier described her disappointing experience with the media: "Disappointment came right at the end of my career, when I already knew that I was going to stop competing, but had not yet told the public. Although TV people already knew about my decision because I had asked them for some videos for a press conference, they kept it quiet as I had requested. Instead, a radio station released the news early and that journalist was even my friend. By chance, I had mentioned my decision to him and he made it public the very same day even though I had asked him to keep it quiet for a while."

This study also examined whether the media had ever offended anyone close to the athletes. The findings indicate that the friends or relatives of athletes are generally respected. However, the following statement by the best Slovenian swimmer speaks for itself: "People close to me got offended because of yellow journalism. I did not even know what it was all about, but I was portrayed as a serious criminal. At first, I was asked for a story and because I did not reply the yellow press decided to make it up on its own. They sent me a text and said they were going to publish it in the section "other business". At home I did not mention that the media had approached me and there was a shock when the commercial for a magazine came on the radio. The title on the front page said "he ran her over" and my picture was next to it. You can imagine how my mother reacted. Nobody informed me, later a psychologist called me and said that one of her students had told her that I had run a girl over and that it was known that I drive recklessly in Koseze $e^{1 .}$."

The results of this study indicate how untrue information published in the media had affected the private lives of athletes. Below are some statements that clarify this issue: "I started to doubt myself, I was sad, nervous and I often argued with people close to me"; "I was thinking why matters about me are so important to the public"; "I could not concentrate on anything, I was mentally down"; "Due to various allegations I found myself in uncomfortable situations in my private life"; "People who met me or knew me slightly kept asking if what they had read was actually true"; "The hardest part is that people who do not know me personally believe the media and have a wrong impression about me".

The media did not affect the sports lives of the majority of the athletes, the consequences of the media's effect on the sports careers of the interviewed subjects are mainly reflected in these statements: "The effect was mostly psychological - poor concentration in trainings, a lack of concentration in the game - it all led to my coach and team mates being unsatisfied and consequently to a bad mood in the team"; "I received fewer offers from other clubs"; "A deal for a transfer to a better club fell through".

The questionnaire offered 12 characteristics related to journalists. The task of the athletes was to define these characteristics according to their importance. In their opinion the qualities most appreciated in journalists are their precision, accuracy and the ability to verify the information and respectfulness (Table 1). Journalists with kind-hearted, impartial and friendly personalities are also much appreciated, followed by those engaging in quality writing. Finally, journalists who have themselves competed in sport events are more appreciated as they guarantee more objective and accurate reports.

Surprisingly, few of the athletes included in the study are aware of the Code of Ethics of Slovenian journalists and that any violations of it are dealt by an Ethics Council of Journalists. In particular, litigation seeking compensation is also an option and these two possibilities may set some legal constraints concerning the dividing line between the public and private lives of athletes. In fact, in this study a limited knowledge of the Code of Ethics of journalists was found, probably because the athletes had only become familiar with it

\footnotetext{
${ }^{1}$ Part of the city of Ljubljana.
} 
when getting into conflict with journalists. Instead, it would be advisable to educate athletes in communication skills because statements can often be misinterpreted, with serious consequences for the sportsperson involved. However, in reality many national sport federations realise the importance of a good relationship with the media and have appointed public relations representatives. Thus, national sports governing bodies should take responsibility for educating athletes without delegating it to coaches.

\section{CONCLUSIONS}

By using a questionnaire and interviewing experienced and less experienced elite Slovenian athletes, the present study reveals their attitudes to the media. In fact, the collected data consist of four segments - general characteristics of the sample of athletes, the attitude of elite athletes to the media, the influence of the media on the private and sports lives of athletes, and the perceived characteristics of good journalists. Although the two groups were similar in several respects (i.e., education, profession, cooperation with the media, monitoring the media before a match, pressure due to the media, athletes or someone close to them being offended by the media, the effect of the media on private and sports lives, perceived characteristics of good journalists), differences emerged regarding the timing of cooperation with the media and whether the media had ever offended an athlete. Elite athletes recognise the media's importance for their sports career and their sponsors. They are therefore quite cooperative with the media and follow the information the media publishes. In particular, young athletes (with a short career) prefer to use the Internet to obtain information.

The majority of the athletes have good experience with journalists, especially when they do not try to interview athletes before a competition. Nonetheless, more than half of the interviewees declared that the media had already offended them, mainly by divulging false or partially true news, which might affect their performance and offend the people close to them. In fact, athletes consider precision, accuracy and the ability to verify information the best qualities of a professional journalist. Accordingly, personal characteristics (i.e., kind-heartedness, arrogance, friendliness...) seem to be less relevant, as do materialistic characteristics (i.e., care for financial success, following the rules and interests of the employer).

Therefore, editors and media owners are strongly recommended to employ highly qualified journalists with a sports background to prevent breaches of the Code of Ethics for journalists. The authors are certain that sports governing bodies which represent athletes should be more proactive in educating elite competi- tors to better manage their relationship with the media to avoid complications and raise the level of cooperation between journalists and athletes.

To enhance the generalisation of these results, future studies should administer the questionnaire to athletes involved in individual sports. In fact, it could be speculated that the media might exert a stronger impact on these athletes because performances rely completely on them and they have no teammates to share their successes or failures. Since it is unreasonable to anticipate a decrease in the media's influence, the results of this study should be regarded as a guideline for sports journalists who work in the good name of sport. Understanding the borderline between the private and public lives of athletes is crucial for establishing a positive relationship with athletes, especially when we consider that these professions are linked to each other.

\section{ACKNOWLEDGMENTS}

We would like to express our very great appreciation to Dr. Bojan Leskošek who helped us calculate the MannWhitney $U$ test and Somer's $D$ test. His willingness to give his time so generously has been very much appreciated.

\section{REFERENCES}

Andrews, D. L., Mason, D. S., \& Silk, M. L. (2005). Qualitative methods in sports studies. Oxford: Berg.

Boyle, R. (2006). Sports journalism: Context and issues. London: Sage.

Coakley, J. (2011). Sports in society. Issues \& controversies. Boston, MA: McGraw-Hill.

Delaney, T., \& Madigan T. (2009). Sports: Why people love them! Lanham, MD: University Press of America.

Deuze, M. (2005). What is journalism? Professional identity and ideology of journalists reconsidered. Journalism, 6, 442.

Doupona Topič, M. (2005). Sport, gender and the issues of life. In K. D. Gilbert (Ed.), Sexuality, sport and the culture of risk (pp. 103-118). Oxford: Meyer \& Meyer Sport.

Entman, R. (1993). Framing: Toward clarification of a fractured paradigm. Journal of Communication, 43(1), 51-58.

Fink, C. C. (1988). Media ethics: In the newsroom and beyond. New York, NY: McGraw-Hill Book Company.

Fink, C. C. (2001). Sports writing. The lively game. Iowa City, IO: Iowa State University Press.

Hardt, H. (1999). Reinventing the press for the age of commercial appeals: Writings on and about public journalism. In T. Glasser (Ed.), The idea of public 
journalism (pp. 197-209). New York, NY: Guilford Press.

Kodeks novinarjev Slovenije [The Code of Ethics of Slovenian Journalists]. (2002). Retrieved from http:// www.razsodisce.org/razsodisce/kodeks_ns_txt. php

Kovach, B., \& Rosenstiel, T. (2007). The elements of journalism. What newspeople should know and the public should expect. New York, NY: Three Rivers Press.

Kustec Lipicer, S., \& Doupona Topič, M. (2012). Sport governance in Slovenia. In C. Sobry (Ed.), Sports governance in the world: A socio-historic approach. The transition in Central and Eastern European sport (pp. 249-274). Paris: Le Manuscrit.

McKnight, D. (2001). Australian media history. Nathan: Australia Key Centre for Cultural and Media Policy.

Merrill, J. C. (1997). Journalism ethics: Philosophical foundation for news media. New York, NY: Martin's Press.

O’Brien, G. (2007). Broadcaster, TSN - 20 years. Broadcaster Magazine. Retrieved from http://www. broadcastermagazine.com/issues/PrinterFriendly. asp?story_id $=50208112537 \& \mathrm{id}=158923 \&$ RType $=$ $\& \mathrm{PC}=\&$ issue $=10022004$

Rowe, D. (2004). Sport, culture and the media: The unruly trinity (2nd ed.). Maidenhead and New York, NY: Open University Press.

Rowe, D. (2007). Still the "toy department" of the news media? Journalism. Sports Journalism, 8(4), 385-405.

Schudson, M. (2001). The objectivity norm in American journalism. Journalism, 2, 149-170.

Schudson, M. (2003). Sociology of news. New York, NY: W.W. Norton.

Tomlinson, A. (2005). Sport and leisure cultures. Minneapolis, MN: University of Minnesota Press.

Wenner, L. A. (Ed.). (1998). MediaSport. London: Routledge.

Wenner, L. A., \& Gantz, W. (1998). Watching sports on television: Audience experience, gender, fanship, and marriage. In L. A. Wenner (Ed.), Media, sports and society (pp. 241-269). Newbury Park, CA: Sage.

Whannel, G. (2002). Media sport stars: Masculinities and moralities. London: Routledge.

Zelizer, B. (2004) Taking journalism seriously: News and the academy. London: Sage.

\section{NĚKTERÉ NÁZORY VRCHOLOVÝCH SPORTOV- CŮ TÝKAJÍCÍ SE SPOLUPRÁCE S MÉDII A VLIV MÉDIÍ NA SPORT A SOUKROMÝ ŽIVOT}

(Souhrn anglického textu)

VÝCHODISKA: Sport je v dnešní době jedním z prvkủ kvality života, protože představuje ukazatel civilizačního, společenského a ekonomického vývoje dané země. Veřejnost se zajímá hlavněo vrcholový sport, což ovlivňuje jak společnost, tak i životy jednotlivců, jelikož veřejnost nezajímají pouze sportovní výsledky, ale také soukromý život sportovců. Je obtížné určit hranici mezi veřejným a soukromým životem. Vzájemně se prolínající práce vrcholových sportovců a médií často vyústí v nepochopení, poněvadž média narušují soukromý život sportovců, což následně ovlivňuje soukromý i profesionální život těchto sportovců.

CÍL: Studie si kladla za cíl zjistit, jaký je postoj vrcholových sportovců $\mathrm{k}$ médiím a jaký mají média vliv na soukromý a profesionální život sportovců. Studie se také zaměřila na to, jaké by měly být vlastnosti ideálního novináře $\mathrm{z}$ pohledu sportovců.

METODY: Na vzorku 67 slovinských sportovců, kteří se zabývají týmovými sporty, byla provedena studie zkoumající rozdíly mezi zkušenými a méně zkušenými sportovci. Data byla shromážděna pomocí dotazníku. Zjištění byla dále srovnána s názory deseti čelných sportovců z oblasti individuálních sportů, jež byly shromážděny pomocí polostrukturovaného rozhovoru.

VÝSLEDKY: Rozdíly mezi skupinami zkušených a méně zkušených sportovců byly zaznamenány $\mathrm{v}$ odpovědích na dotazy: „Kdy se sportovci rozhodnou spolupracovat s médii?" a "Zažili jste někdy urážku ze strany médii?'“. Vrcholoví sportovci s médii rádi spolupracují a obvykle jim otevřeně poskytují informace. Stejně tak novináři do velké míry chápou, že sportovci před utkáním či závodem potřebují klid na př́pravu. Sportovci mají za to, že nejdůležitější vlastnosti novináŕů jsou přesnost a schopnost ověrit si informace, zatímco osobní vlastnosti a materialistické charakteristiky vnímají jako méně významné.

ZÁVĚRY: Výsledky studie naznačují, že sportovci by si přáli, aby o nich novináři psali články, které budou méně urážlivé, a to bez ohledu na to, zda se zveřejněné informace týkaji jejich sportovních výsledkủ, nebo soukromého života.

Klićová slova: média, novinárství, soukromí, verejnost, sport. 